\title{
An empirical research study on prospect- refuge theory and the effect of high-rise buildings in a Japanese garden setting
}

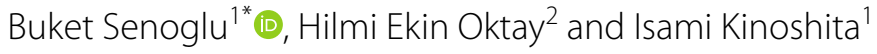

\begin{abstract}
This study was carried out to test prospect-refuge theory and the effect of external high-rise buildings on landscape preferences in a traditional Japanese daimyo (feudal lords) garden, namely, the Hama-rikyu Gardens located in Tokyo, Japan. Eight sites in the garden were selected to be tested with respect to their degree of openness, their degree of safety, and the ratio of background buildings present. An in situ survey was conducted with 129 people (15-18 per site) who agreed to take part in the survey. Subjects were asked to assess the view at each site in the direction indicated by a sign and to provide responses about (a) their general preference for the view, (b) their perception of the openness of the view, (c) their perception of the safety of the site, (d) their perception of the pleasantness of/ disturbance from the background buildings. The results indicated that predefined open-protected sites were more preferred than the others; prospect (perceived openness) was an important indicator of the preferences, whereas the refuge-related symbols (perceived safety) of the garden were not perceived differently between the sites; the ratio of background buildings did not have a significant effect on either landscape preferences or perceived prospect-refuge attributes, whereas the perceived pleasantness of/disturbance from background buildings significantly affected the overall landscape preferences. The results indicated that the design techniques of Japanese daimyo gardens, including the usage of the Shakkei (borrowed scenery) technique, might reveal the principles of prospect-refuge theory. Furthermore, the effect of the surrounding buildings is considered to be a subjective aspect that depends on observers' experiences and attitudes, rather than an objective one.
\end{abstract}

Keywords: Japanese daimyo garden, Prospect-refuge theory, Landscape preference, Shakkei, Borrowed scenery, High-rise building, Hama-rikyu

\section{Introduction}

The scenic beauty of landscapes or, in a broader sense, landscape aesthetics has been an area of interest for assessing the visual quality of gardens and landscapes, as well as the preferences for them (Kaymaz 2012). There are various theories that try to explain landscape preferences with both evolutionary and cultural approaches, such as the biophilia hypothesis (Wilson 1984), habitat theory (Orians 1980), prospect-refuge theory (Appleton 1975a), information processing theory (Kaplan and

\footnotetext{
*Correspondence: senoglubuket@gmail.com

1 Department of Landscape Architecture and Environmental Science, Chiba University Graduate School of Horticulture, 648 Matsudo, Matsudo City, Chiba 271-8510, Japan

Full list of author information is available at the end of the article
}

Kaplan 1989), topophilia theory (Tuan 1974), ecological aesthetics (Nassauer 1992), genius loci (Norberg-Schulz 1980), the landscape heritage approach (Fairclough et al. 1999) and the aesthetics of care (Nassauer 1995, 1997).

Prospect-refuge theory, as one of the evolutionarybased theories in the environmental aesthetics discipline, plays an essential role in understanding landscape preferences (Appleton 1975a). Prospect-refuge theory was created in a theoretical vacuum (Appleton 1975b), at a time when there was plenty of empirical research on landscape preferences, but none of this research was grounded in a strong theoretical base (Zube et al. 1982, 1987). Prospect-refuge theory enabled the explanation of some empirical findings, as well as the emergence of some other theories about landscape aesthetics, such as 
habitat theory (Orians 1980), biophilia theory (Wilson 1984), affective theory (Ulrich 1983, 1993) and information processing theory (Kaplan and Kaplan 1989; Kaplan et al. 1998).

Prospect-refuge theory focused on the role of humans in prehistoric times as being both predators and prey in nature. From this perspective, Appleton (1975a) underlined the importance of "seeing without being seen" in order to hunt without being hunted and stated that natural selection has led humans to prefer settings in which they have the opportunity to see (prospect) without being seen (refuge). In this respect, Appleton (1975a) stated that landscapes where human can experience aesthetic satisfaction should possess both refuge- and prospectrelated features in balanced proportions.

Several consistent studies have considered prospectrefuge theory as a valid explanation for human responses to the environment, and the theory has become accepted in design disciplines as a proper way to create ideal spaces (Kellert 2005; Lippmann 2010; Dosen and Ostwald 2016). Thus, it has become probably the most wellknown theory for explaining environmental preferences in the urban, architectural and interior design disciplines (Dosen and Ostwald 2016) along with the studies regarding preferences for natural environments. The relationship between prospect-refuge theory and landscape preferences has therefore been established through previous empirical research. Previous empirical studies were conducted in a variety of spatial settings, including natural, urban and interior environments (Dosen and Ostwald 2016). One of the most cited of these studies was conducted in a campus setting (Nasar et al. 1983); other studies were conducted in a natural recreational setting (Ruddell and Hammitt 1987), in various conditions with various subjects, including children, via a set of experiments (Conrad 1993), in a cultural landscape setting (Hagerhall 2000), in a waterfront urban park setting (Mumcu et al. 2010), and in Japanese Zen gardens to reveal the effect of enclosure on preferences (Inagami 2013; Inagami 2014).

Introduced in the early Meiji period (1868-1912), the idea of aesthetics in the Western sense as the philosophical study of beauty is a relatively recent one in Japan. However, aesthetic concepts, which are collectively referred to as Japanese aesthetics, have existed far longer than the philosophy of aesthetics in the west, and they have been applied within several contexts, such as art, gardens, natural features and even everyday activities (Timmons 2012). With regard to Japanese gardens, it has been observed that the aesthetic sense used in the design of these gardens follows environmental aesthetic theories prevalent in the current literature. In this context, it is thought that the Japanese aesthetic concept responds to the requirements of the environmental aesthetic theories developed in the west. Studies that have examined the link between environmental aesthetic theories and Japanese gardens (Appleton 1975a; Orians 1980; Kaplan and Kaplan 1989; Kaplan et al. 1998; Stamps 2014) also support this hypothesis. However, the number of empirical studies that have tested this relationship (Yang and Brown 1992; Kaplan et al. 1998; Inagami 2013; Inagami 2014) is still limited. Moreover, the studies that have focused on testing prospect-refuge theory in Japanese gardens (Inagami 2013, 2014) are scant. Although the validity of prospect-refuge theory in Japanese gardens was discussed by Inagami $(2013,2014)$, his research mainly concentrated on the effect of the refuge aspect on the attractiveness of Japanese Zen gardens. Nevertheless, the question of how prospect affects the experience of Japanese gardens remains. Furthermore, Appleton (1975a) linked his theory with Japanese garden design style mainly through refuge-related aspects, while he considered the prospect-related character of the gardens only through the presence of an ornamental mount (Appleton 1975a; 1996). After citing a paragraph from Tamurai's (1935) book, Appleton indicated that:

\begin{abstract}
"In spite of differences between Japan and Western garden and the "taste," it is not difficult to find an underlying unity of concept in prospect-refuge terms. ...... Japanese garden lays more emphasis on refuge symbols ("dusky shades," "twilight profundity") than its dominant western counterpart ("sunny openness" "as open as possible"). In the details of design, we find in Japanese garden an entirely different idiom... Japanese garden examples convince us that an unfamiliar arrangement of unfamiliar vegetation, however much it symbolizes an unfamiliar religious philosophy, is certainly not grafted on to an unfamiliar basic composition. Here is encircling fence to create a refuge. Here is the ornamental "mount" to permit a prospect."
\end{abstract}

(Appleton 1996)

However, it is thought that there are some traditional Japanese gardens in which prospect-related aspects are as prevalent as refuge-related aspects. For instance, Daimyo (feudal lords) gardens of the Edo period (1603-1868) are thought to be the best examples that exhibit both the prospect and refuge aspects of a Japanese garden.

Daimyo gardens of the Edo period were a new prototype with design features that included strolling gardens (kaiyu-shiki teien) and borrowed scenery (shakkei) (Arifin and Masuda 1997). The strolling gardens (kaiyu-shiki teien) were designed along a path that circled the garden to allow enjoyment of consecutive views (Ito and 
Kawarada 2000). In the Edo period, openness was a new visual concept that was introduced with daimyo gardens, and the practice of strolling around gardens subsequently developed to take full advantage of this openness (Shirahata 2016). These gardens focused attention not only on internal features but also on outward views with the practice of borrowed scenery (Shakkei), which is the design technique of incorporating distant landscapes into the garden composition (Sullivan and Boults 2010). In this sense, the background view was carefully organized to complete the overall scenery of gardens. Both natural features, such as mountains, hills and plains, rivers, the ocean and even the sky, and human-made structures, such as temple gates and pagodas, could be used in these gardens as borrowed scenery (Nitschke 1993).

These two design concepts of Japanese daimyo gardens, namely, kaiyu-shiki teien (strolling garden) and Shakkei (borrowed scenery), are considered important sources of evidence for both prospect and refuge aspects in traditional Japanese gardens. It is thought that the openness of these grand-scale gardens emphasizes the prospect aspect. The Shakkei technique also fits the concept of prospect-refuge theory by enabling the observer to see distant views without being seen. However, no existing research considers the relation between the design concepts of daimyo gardens and prospect-refuge theory.

Japanese daimyo gardens, which focused attention on both internal features and distant views (Sullivan and Boults 2010), also took full advantage of the native landscape and terrain of Edo city (which is now modern-day Tokyo) (Shirahata 2016). As a result, these gardens exhibited background views from the application of Shakkei (borrowed scenery) of natural landscapes such as Mt. Fuji (Shinji 2015), a natural landmark that has been prized since ancient times as a site of spiritual and cultural significance (Scoble 2015). However, today in Tokyo city, it is difficult to investigate the effect of the original application of Shakkei on the aesthetic experience of these gardens, as these gardens have been surrounded by high-rise buildings and have lost their original Shakkei (borrowed scenery) due to urbanization and redevelopment projects in recent decades. In this respect, the studies that concentrate on the high-rise building effect on traditional Japanese gardens (Shinji et al. 1989; Arifin and Masuda 1997; Koizumi and Ishikawa 2007; Shinobe 2012; Akasaka 2014; Lin et al. 2017) explain the existence of visible buildings as a negative element that destroys the original spirit of the gardens and emphasize the urgent need for control to reduce this negative effect. On the other hand, it is observed that these background views filled with buildings are sometimes interpreted as a 'modern concept of Shakkei', as the modern high-rise buildings have replaced the original borrowed sceneries, such as Mt. Fuji (Anonymous 2016a), and the contrast of modern and traditional is even appreciated by some (TMPA 2006; Anonymous 2015, 2016b). Regarding these divergent perspectives about the visual effect of highrise buildings on traditional Japanese gardens, it seems important to examine this effect in both objective and subjective manners. Despite this, previous studies about the visual impact of high-rise buildings on the traditional Japanese gardens have only addressed the issue from an objective approach (Shinji et al. 1989; Arifin and Masuda 1997; Koizumi and Ishikawa 2007; Shinobe 2012; Akasaka 2014; Lin et al. 2017), while the studies gauging visitor's preferences are limited (Arifin and Masuda 1998).

In this sense, there is a need for a study that focuses on the relation between environmental aesthetic theories and Japanese daimyo gardens in Tokyo and takes into account the effect of high-rise buildings on the environmental aesthetics of their scenery (which, in turn, could affect the aesthetic experiences of their visitors). Such a study could employ a psychophysical model with an approach to examine the issue in both positivistic (preferences procured by measurable physical characteristics) and psychological (individuals' personal experiences) terms.

Prospect-refuge theory had been tested in some other studies and provided a valid explanation for landscape preferences as previously discussed, but there are limited empirical studies that explain the relation between traditional Japanese garden principles and environmental aesthetics. Therefore, the overall scope of this study is to obtain user perceptions of and attitudes towards a traditional Japanese garden's visual aesthetic features in order to use them as an indicator for sustainable and participatory management. Based on the general scope, a traditional Japanese garden was examined in light of the landscape aesthetics theories. In this study, we aim to find evidence for prospect-refuge theory in a traditional Japanese daimyo garden in the context of visitor perception and attempt to examine the visual effect of the surrounding high-rise buildings on the aesthetic experiences of users. In accordance with these aims, this research has six objectives:

i. To identify general landscape preferences for the selected sites.

ii. To test prospect-refuge theory and determine its effects.

iii. To find evidence for the relation between the Shakkei (borrowed scenery) technique and prospect-refuge theory.

iv. To test the effect of socio-demographic characteristics of the observers on their perception of landscape preferences in accordance with prospect-refuge theory. 
v. To identify the visual effect of the surrounding highrise buildings on general landscape preferences.

vi. To identify the visual effect of the surrounding high-rise buildings on prospect- and refuge-related aspects.

By investigating the objectives listed, the overall aim was to test the validity of environmental aesthetic theories, particularly Appleton's prospect-refuge theory, in a Japanese garden for the purpose of contributing to the related literature. Furthermore, by testing whether building intrusion affects users' landscape preferences and their perceptions of prospect-refuge aspects, this paper attempted to reveal the effect of the high-rise buildings on garden aesthetics.

The European Landscape Convention (2002) describes landscape as an area perceived by people whose character is the result of the actions and interactions of natural and/or human factors. In this context, landscape involves a subjective experience. Therefore, empirical studies gauging user perceptions are essential to environmental aesthetics research. It is known that preferences can be shaped by social, cultural, and personal characteristics of individuals. By collecting information on the sociodemographic attributes of the users, this study aimed to contribute to the ongoing discussion in the philosophy of aesthetics of whether the beauty is an objective truth or in the eyes of the beholder.

Generalizations of the results of this study to broader contexts are somewhat limited. Due to budget and time restrictions, only eight different sceneries were selected to be assessed by the users. Different users also assessed different sceneries, which may affect the consistency of the results and limits the ability to make direct comparisons between the sites. Nevertheless, this study may still contribute to the related literature by investigating the concepts of prospect-refuge theory in a Japanese garden in the context of user perception.

\section{Methods}

An in situ survey was conducted to measure the visitors' experiences of prospect- and refuge-related features using a sample of both foreign and local visitors to a traditional Japanese garden called the Hama-rikyu Gardens. Eight sites in the garden were selected to be tested with regard to the degree of openness, the degree of safety of the site, and the ratio of background buildings present.

\section{Study area}

Hama-rikyu Gardens is a typical stroll-type (kaiyu-shiki teien) daimyo garden of the Edo period (Koizumi and Ishikawa 2007; Shirahata 2016). The garden is located in the Chuo Ward of Tokyo Metropolitan City, Japan and covers an area of 250,215.72 $\mathrm{m}^{2}$ (Fig. 1). The current form of the garden was completed around the time of the 11th Shogun, Ienari (1773-1841). After the Meiji Restoration (1868), the garden became a detached palace for the Imperial family and was officially named Hamarikyu, which literally means 'a detached palace on the coast'. In 1945, the Imperial family donated the garden to the Tokyo Metropolitan Government, and it was opened to the public in 1946. The garden was declared a Special Place of Scenic Beauty and a Special Historic Site in 1952 by the Cultural Properties Protection Law of Japan (TMPA 2008).

Beyond its designation as a grand-scale stroll-type garden, Hama-rikyu Gardens made use of distant sceneries with the Shakkei technique (Shinji 2015). However, its original borrowed sceneries, which included Tokyo Bay, the Boso Peninsula, Shinagawa Bay, Mt. Tsukuba and Mt. Fuji, have disappeared due to urbanization, resulting in its current state of being surrounded by high-rise buildings (Shinji 2015; TMGBCPD 2017).

As a widely appreciated and popular garden in the center of Tokyo city, Hama-rikyu Gardens reflects the traditional stroll-type Japanese gardens of the Edo period and hosts many Japanese and foreign visitors each year, regardless of the season. On the other hand, there has been an ongoing debate about the impact of surrounding high-rise buildings on the scenery of the garden and the loss of its original borrowed scenery (Shinji et al. 1989; Koizumi and Ishikawa 2007; Akasaka 2014; Shinji

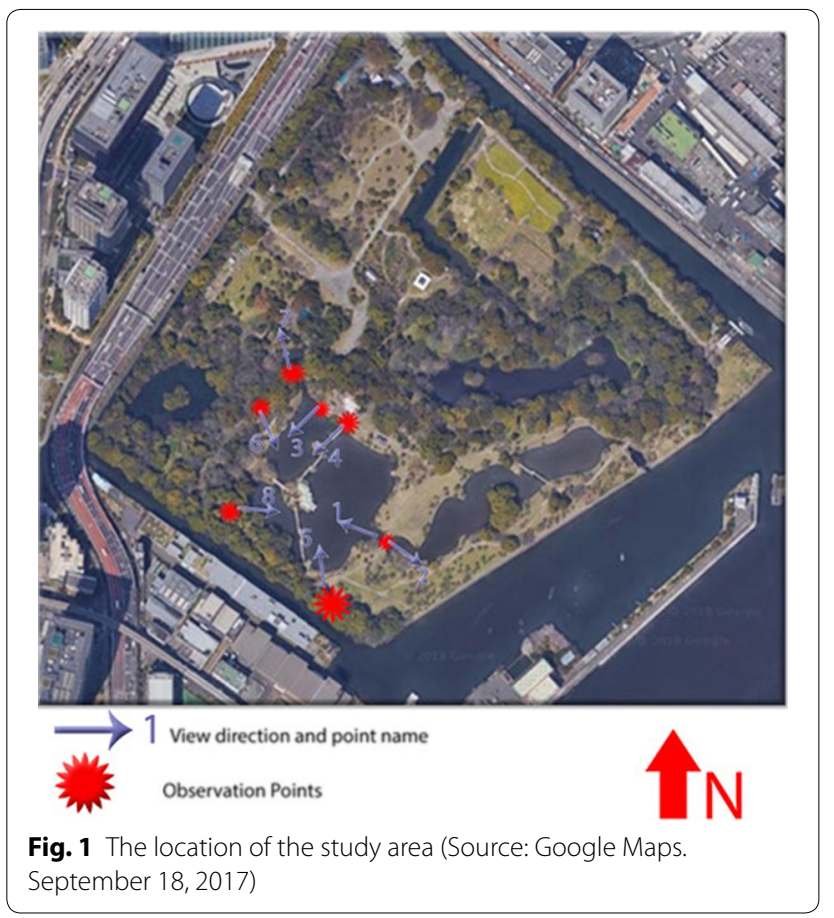


2015). However, the previous studies conducted with this garden (Shinji et al. 1989; Koizumi and Ishikawa 2007) determined the impact of high-rise buildings in an objective manner, while the question of how these sceneries are assessed by the visiting public remains unanswered.

Therefore, Hama-rikyu Gardens was selected as the research setting for its proper representation of traditional Japanese daimyo gardens in which prospect-refuge theory can be examined and the visual effect of the surrounding high-rise buildings can be taken into consideration, especially in the context of visitors' experiences, as no previous studies have considered this.

\section{The criteria for site selection}

For the selection of the sites in the garden, the arrangement and configuration of the space were defined based on a classification offered by Nasar et al. (1983) and Conrad (1993) for experimental studies on prospect-refuge theory. Two bipolar spatial assessment scales were used to categorize the environments: an open-closed scale and a protected-unprotected scale. Based on this categorization, observation points from which broad, unobstructed views were available were chosen to provide the 'open views' associated with the prospect aspect. On the opposing end of the scale, 'closed views' were obstructed by some landscape elements. 'Protected observation points' associated with the refuge were chosen to be locations where the observer could partially hide from her/his surroundings. On the opposite end of the scale, 'unprotected observation points' were locations that lacked features with which individuals could hide from view.

Four conditions that had been used in a previous study (Nasar et al. 1983) were considered as a priori conditions: (1) an open view with an unprotected observation point; (2) a closed view with an unprotected observation point; (3) an open view with a protected observation point; and (4) a closed view with a protected observation point. Additionally, all of the sites were selected to have a view of water elements (ponds) in the garden since it is known that water elements profoundly influence the visitors' affective appraisals and are preferred to other landscape elements (Kaplan and Kaplan 1989; Kaplan et al. 1998).

First, 36 sites on the main route in the garden were selected and photographed by a DSLR camera with an EF-S18-55 mm, f 3.5-5.6 lens. All the photos were shot with the widest angle possible and open focus $(18 \mathrm{~mm}$ focal length, the focus of the photos varies from $\mathrm{f} 6-8$ ). The 36 sites were defined and split into the four categories above according to the assessment of the authors. To calculate the density of external high-rise buildings included in the scenery of each site, a vectoral drawing program (AutoCad 2017) was used. The borders of the buildings in each scene were drawn to achieve a closed shape, and the ratio of buildings to the entire scenery in the frame of each photograph was measured for each site. Then, for each category, the average building density was calculated. The sites with higher ratios than the average were considered "high-level density" sites, while those with lower ratios than the average were considered "low-level density" sites. Lastly, for each category, two sites (one site with a high-level density and one site with a low-level density of buildings) were selected. As a result, eight sites (two for each condition) were selected for examination (Fig. 2).

To represent the first condition (an open view with an unprotected observation point), the observation point is a bridge (Nakanohashi) over a pond without features to hide an individual from the surroundings. This observation point provides an open view without any obstacles both to the north-west (1) and the southeast (2). For the second condition (a closed view in an unprotected site), the observation points were open spaces lacking landscape features with which to hide. The scenery of observation point 3 was obstructed by a Wisteria trellis, while a traditional structure (teahouse) served as the obstruction element for the scenery of observation point 4. The observation points for the third condition (an open view in a protected site) were both artificial hills providing a secure feeling with trees on the sides and behind. The tree branches stretched out above the observer but did not interfere with the view. From the top of Mt. Fujimi (5), one could see an overall view of the main pond, bridges, and teahouses. Similarly, at the top of Mt. Hakkei (6), the view was open to scenery, which included the main pond, bridges, and teahouses. The observation points for the fourth condition (a closed view in a protected site) were chosen as locations where one could feel hidden due to the presence of dense trees and bushes on the sides and behind. The scenery of Sangenbashi Bridge (7) was obstructed by tree branches, and a high-rise building was located close by, which created an effect similar to the presence of a wall. The other observation point in the same condition (8) offered scenery that was obstructed by a small hill right in front of the standing point, as well as dense trees obstructing the view of the main pond and the other landscape elements. It should be noted that since Hama-rikyu Gardens is surrounded by high-rise buildings and these buildings are visible from almost every unobstructed observation point, the building density in the sceneries of the 'open views' are always higher than they are in the 'closed views'. As mentioned previously, the categorization of the building density (high level-low level) was determined for the sites representing each condition. 


\section{(1) Open View - Unprotected site}

\section{High Building Density}

1. Nakanoshashi Bridge; looking towards Dai-sensui pond

\section{Low Building Density}

2. Nakanohashi Bridge;

looking towards

Yokobori pond
(2) Closed View - Unprotected site

\section{High Building Density Low Building Density}

3. In front of Wisteria

trellis part of

Otsutaibashi Bridge
4. Next to

Tsubame-no-ochaya

teahouse

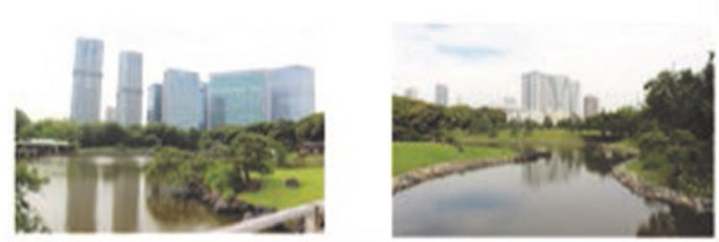

(3) Open View - Protected site

High Building Density

5. Mt. Fujimi

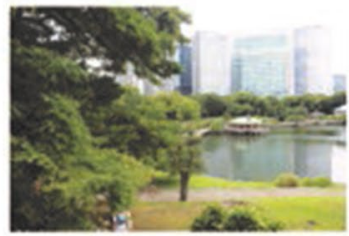

Low Building Density

6. Mt. Hakei

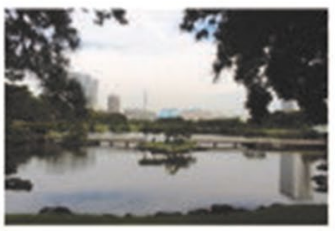

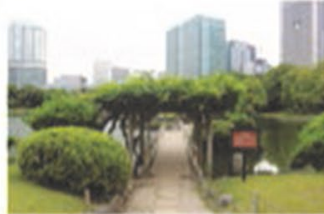

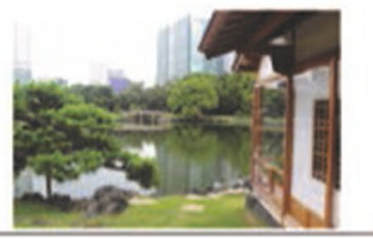

(4) Closed View - Protected site

High Building Density

7. Sangenbashi Bridge

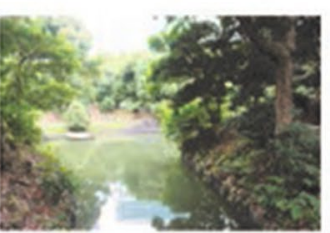

Low Building Density

8. The Forest surrounding Dai -sensui pond

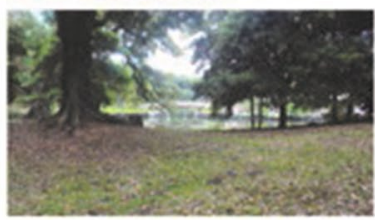

Fig. 2 The selected sites and their views

\section{The questionnaire}

In the questionnaire, a variety of statements to measure the perceived safety, openness and building influence were presented on a 5-point Likert scale ranging from $1=$ 'not at all' to $5=$ 'very much.' The questions asked in the questionnaire and the logic behind them are given in Table 1.

\section{Subjects}

The sampling population for the survey was selected to be the visitors of Hama-rikyu Gardens. The selection of subjects was performed by using a purposeful quota sampling method. In light of this sampling method, 15 people per site was determined to be a sufficient sample size for statistical tests to be performed and was defined as the minimum quota for sampling. A total of 143 people were asked to participate in the survey, of whom $10 \%$ declined to participate. As a result, 129 (70 male, 59 female) visitors (between 15 and 18 per site) voluntarily took part in the study. Each subject was stopped, one at a time, at the observation points on a clear day of August (12.08.2017). Different people were questioned at each observation point. Hama-rikyu Gardens' role as a tourist attraction in the center of Tokyo allowed this study to test the influence of cross-cultural attributes as well. The demographic composition of the sample included 64 participants who were foreign visitors, while 65 of the participants were Japanese. Furthermore, visitors to Hama-rikyu Gardens spanned many age groups. In the sample, participants in the survey were in the age range from 12 to 76 years old, and the mean age of the participants was 35.6.

\section{Table 1 Questionnaire items and logic behind them}

\begin{tabular}{|c|c|}
\hline I like the scene from this point & To obtain data about general preference \\
\hline $\begin{array}{l}\text { The scene from this point is } \\
\text { open/closed }\end{array}$ & $\begin{array}{l}\text { To obtain data about perceived pros- } \\
\text { pect }\end{array}$ \\
\hline $\begin{array}{l}\text { The point at which I stand is } \\
\text { safe/unsafe }\end{array}$ & To obtain data about perceived refuge \\
\hline $\begin{array}{l}\text { The building in the back- } \\
\text { ground of the scene is } \\
\text { disturbing/pleasant }\end{array}$ & $\begin{array}{l}\text { To obtain data about the attitudes of } \\
\text { respondents towards background } \\
\text { buildings }\end{array}$ \\
\hline Gender & $\begin{array}{l}\text { To obtain data about respondents' } \\
\text { demographic background }\end{array}$ \\
\hline Age & $\begin{array}{l}\text { To obtain data about respondents' } \\
\text { demographic background }\end{array}$ \\
\hline Income & $\begin{array}{l}\text { To obtain data about respondents' } \\
\text { demographic background }\end{array}$ \\
\hline Education & $\begin{array}{l}\text { To obtain data about respondents' } \\
\text { demographic background }\end{array}$ \\
\hline Occupation & $\begin{array}{l}\text { To obtain data about respondents' } \\
\text { demographic background }\end{array}$ \\
\hline
\end{tabular}


Demographic characteristics of the respondents can be seen in Table 2.

\section{Procedure}

Visitors who were passing by were asked if they would like to participate in the study. The interviewer handed the instruction sheet and the questionnaire to the participant and asked them to read the instructions. The participant filled out the questionnaire by standing at the specific point for each site and looking in the direction that was indicated by an arrow sign. The standing point and the sign indicating the viewing direction were printed on an A4 paper and placed in the area where the participant was asked to stand.

\section{Analysis}

A variety of statistical analyses were performed to reveal the relationships between the variables. Variance tests were conducted to measure the mean difference among the sites individually, among the sites regarding the categories (open, closed, protected, unprotected) and between shakkei and non-shakkei points, building ratio groups (high-level density, low-level density), gender and nationality. Regression analysis was performed to test all the variables for their influence on general landscape preferences. Finally, correlation analysis was employed to reveal the effect of high-rise buildings on general landscape preferences and prospect-refuge aspects.

\section{Results}

General landscape preferences (like/dislike)

Analysis showed that there was no significant difference between the sites regarding general landscape preferences (like/dislike) $(\mathrm{F}=1.971, d f=7-121, \mathrm{p}>0.05)$. The results showed that the mean value of all the sites was 3.78. However, the most preferred site was Mt. Fujimi, while the least was Sangenbashi Bridge, with mean preferences of 4.2 and 3.12, respectively (Table 3; Fig. 3).

\section{Refuge aspect}

When we look at the perceived safety of the sites in association with their refuge-related characteristics, no significant difference was found among them $(F=0.166$, $d f=1-127, \mathrm{p}>0.5)$. The results showed that the mean value of all the sites was 4.33 . The sites that were predefined as protected (refuge) had a mean perceived safety score of 4.35 , while the sites that were predefined as unprotected (not refuge) had a mean perceived safety score of 4.30. In this case, it can be observed that all the sites have high mean perceived safety scores. Thus, we cannot examine the effect of refuge on landscape preferences, and all the sites can be labeled as refuge in the visitors' perception $(\mathrm{F}=1.636, d f=7-121, \mathrm{p}>0.05)$ (Table 3$)$.

\section{Prospect aspect}

When we examined openness/closedness of the views in association with their prospect-related features, a significant difference was found among them $(\mathrm{F}=18.030$, $d f=1-127, \mathrm{p}<0.001)$. The results showed that the mean openness score across all the sites was 3.41.

The predefined open (prospect) views had a mean perceived openness score of 3.78, while the predefined closed (not prospect) views had a mean perceived openness score of 3.03. This difference indicates that our

Table 2 Demographic background of respondents

\begin{tabular}{|c|c|c|c|c|c|c|}
\hline Gender & Female & Male & & & & \\
\hline $\mathrm{N}$ & 59 & 70 & & & & \\
\hline$\%$ & 45.7 & 54.3 & & & & \\
\hline Age & Under 23 & $23-40$ & $41-60$ & 61 and above & & \\
\hline $\mathrm{N}$ & 20 & 65 & 38 & 6 & & \\
\hline$\%$ & 15.5 & 50.4 & 29.5 & 4.7 & & \\
\hline Income & 0 & $1-549,999$ & $550,000-2,999,999$ & Above $3,000,000$ & Missing & \\
\hline $\mathrm{N}$ & 3 & 21 & 21 & 22 & 62 & \\
\hline$\%$ & 2.3 & 16.3 & 16.3 & 17.1 & 48.1 & \\
\hline Education & Elementary & Junior-high school & High-school & Bachelor's & Master's & Ph.D. \\
\hline $\mathrm{N}$ & 1 & 5 & 23 & 79 & 16 & 5 \\
\hline$\%$ & 0.8 & 3.9 & 17.8 & 61.2 & 12.4 & 3.9 \\
\hline Nationality & Japanese & Foreign & & & & \\
\hline$N$ & 65 & 64 & & & & \\
\hline$\%$ & 50.4 & 49.6 & & & & \\
\hline
\end{tabular}


Table 3 Mean scores of the sites

\begin{tabular}{|c|c|c|c|c|c|c|c|c|}
\hline \multirow[t]{2}{*}{ Name of the site } & \multicolumn{3}{|l|}{ Predefined } & \multicolumn{4}{|c|}{ Perceived } & \multirow[t]{2}{*}{$\mathbf{N}$} \\
\hline & Open/closed & $\begin{array}{l}\text { Protected/ } \\
\text { unprotected }\end{array}$ & $\begin{array}{l}\text { Building } \\
\text { ratio } \\
\text { in scene } \\
(\%)\end{array}$ & $\begin{array}{l}\text { Mean } \\
\text { score } \\
\text { of like }\end{array}$ & Closed/open & Unsafe/safe & $\begin{array}{l}\text { Building } \\
\text { disturbing/ } \\
\text { pleasant }\end{array}$ & \\
\hline 1. Nakanohashi bridge-1 & O & UP & 35.08 & 3.94 & 3.31 & 4.31 & 3.12 & 16 \\
\hline 2. Nakanohashi bridge-2 & $\mathrm{O}$ & UP & 5.55 & 3.94 & 4.00 & 4.31 & 2.93 & 16 \\
\hline $\begin{array}{l}\text { 3. In front of Wisteria trellis part of } \\
\text { Otsutaibashi bridge }\end{array}$ & C & UP & 16.94 & 3.86 & 3.60 & 4.33 & 3.40 & 15 \\
\hline $\begin{array}{l}\text { 4. Next to Tsubame-no-ochaya } \\
\text { teahouse }\end{array}$ & C & UP & 7.80 & 3.71 & 3.23 & 4.23 & 2.76 & 17 \\
\hline 5. Mt. Fujimi & O & $P$ & 14.54 & 4.20 & 3.80 & 4.60 & 3.47 & 15 \\
\hline 6. Mt. Hakkei & O & $P$ & 2.70 & 4.00 & 4.00 & 4.44 & 3.11 & 18 \\
\hline 7. Sangenbashi bridge & C & $P$ & 3.45 & 3.12 & 2.35 & 3.82 & 3.23 & 17 \\
\hline $\begin{array}{l}\text { 8. The forest surrounding Dai-sensui } \\
\text { pond }\end{array}$ & C & $P$ & 0.39 & 3.53 & 3.00 & 4.60 & 3.47 & 1 \\
\hline Total & & & & 3.78 & 3.41 & 4.33 & 3.17 & 12 \\
\hline
\end{tabular}

C closed, $O$ open, UP unprotected, $P$ protected

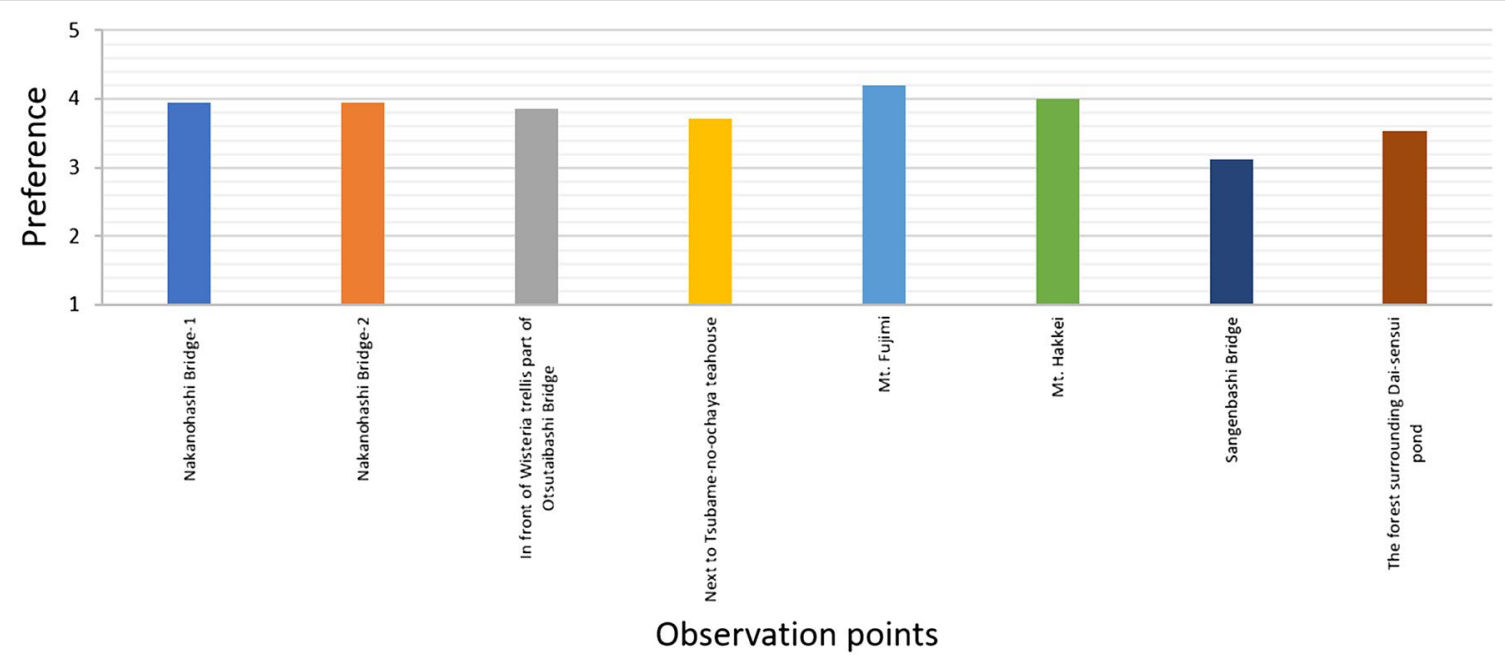

Fig. 3 Mean preference scores of the sites

analyses of the landscape preferences of visitors to Hamarikyu Gardens can rely mainly on prospect aspects.

When we examined the general landscape preferences for the sites by the perceived openness of the scenes, it was observed that degree of openness was significantly related to general landscape preferences $(\mathrm{F}=4.604$, $d f=4-124, \mathrm{p}<0.005)$ and that the open scenes had a greater mean preference score (4.47) than the closed ones (2.67) (Table 3).

\section{The effect of prospect-refuge on general landscape preferences}

In an attempt to examine the effect of prospect-refuge on general landscape preferences, the predefined categories were tested (Table 4). The results of the analysis showed a significant difference between the categories $(\mathrm{F}=3.979$, $d f=3-125, \quad \mathrm{p}<0.05)$. The predefined open-protected (prospect-refuge) sites were the most preferred ones (mean: 4.09), whereas the predefined closed-protected sites were the least preferred (mean: 3.31) (Fig. 4).

\section{Prospect-refuge and Shakkei}

The two artificial hills in the garden enable the observer to see a broad panorama, and Mt. Fujimi and Mt. Hakkei had background views of natural elements in the Edo period. It is said that in the Edo period, Mt. Fujimi had a view of Mt. Fuji, Mt. Tsukuba, Edo Bay (Tokyo Bay) and the mountains of the Boso Peninsula. Mt. Hakkei 
Table 4 One-way ANOVA test results of landscape preferences for predefined sites

\begin{tabular}{lllllll}
\hline & Point type & N & Mean & Std. dev. & df & F \\
\hline Landscape preference & Open-unprotected & 32 & $3.94^{\mathrm{a}}$ & 0.88 & $3-125$ & 3.979 \\
& Closed-unprotected & 32 & $3.78^{\mathrm{ab}}$ & 1.18 & & \\
& Open-protected & 33 & $4.09^{\mathrm{a}}$ & 0.80 & & \\
& Closed-protected & 32 & $3.31^{\mathrm{b}}$ & 0.93 & & \\
& & & & & \\
\end{tabular}

a, ab, b Groups in Tukey's test ("a" indicates the most preferred group whereas "b" is the least preferred group)

was also an important point with background views that included the ocean and the mountains (TMGBCPD 2017). In light of this information, we can infer that these two artificial hills were sites from which the Shakkei (borrowed scenery) technique could be experienced. When we look at the mean preferences for these sites (Table 3; Fig. 3), the most preferred observation points were Mt. Fujimi and Mt. Hakkei, with the mean preference scores of 4.2 and 4.0, respectively. Therefore, in an attempt to identify general landscape preferences and the perceived openness (prospect) and safety (refuge) of these two artificial hills in comparison with the other six sites, Mt. Fujimi and Mt. Hakkei were categorized together in a group under the name of 'shakkei points', while the other six sites were categorized in a group called 'non-shakkei points.' According to the analysis, 'shakkei points' (4.09) were found to be significantly more preferred than 'nonshakkei points' (3.68) $(\mathrm{F}=4.206, d f=1-127, \mathrm{p}<0.05)$. Furthermore, 'shakkei points' (3.91) were perceived as significantly more open than 'non-shakkei points' (3.24) $(\mathrm{F}=10.263, d f=1-127, \mathrm{p}>0.005)$. The fact that the given F statistic is high in parallel with the mean scores can be interpreted as a sign that these two sites (Mt. Hakkei and Mt. Fujimi) have higher values with regard to prospect qualities compared to the other six sites. In addition, 'shakkei points' were perceived to be safer (4.52) than 'non-shakkei points' (4.26), but the difference was not significant $(\mathrm{F}=2.571, d f=1-127, \mathrm{p}>0.05)$ (Fig. 5).

\section{Effect of gender}

When group differences were examined, no significant difference was found between male and female participants in terms of their general preferences for the sites $(\mathrm{F}=0.458, d f=1-127, \mathrm{p}>0.05)$. Their mean preference scores were 3.73 and 3.85 , respectively. However, when the predefined sites were individually examined, it was found that 'open-unprotected' sites were preferred significantly more by female participants (4.31) than male participants $(3.68)(\mathrm{F}=4.312, d f=1-30, \mathrm{p}<0.05)$. For the other categories, gender differences in landscape preferences were not significant (open-protected: $F=2.328$, $d f=1-31, \mathrm{p}>0.05$; closed-protected: $\mathrm{F}=0.066, d f=1-30$, $\mathrm{p}>0.05$ closed-unprotected: $\mathrm{F}=0.962, \quad d f=1-30$, $\mathrm{p}>0.05$ ) (Fig. 6).

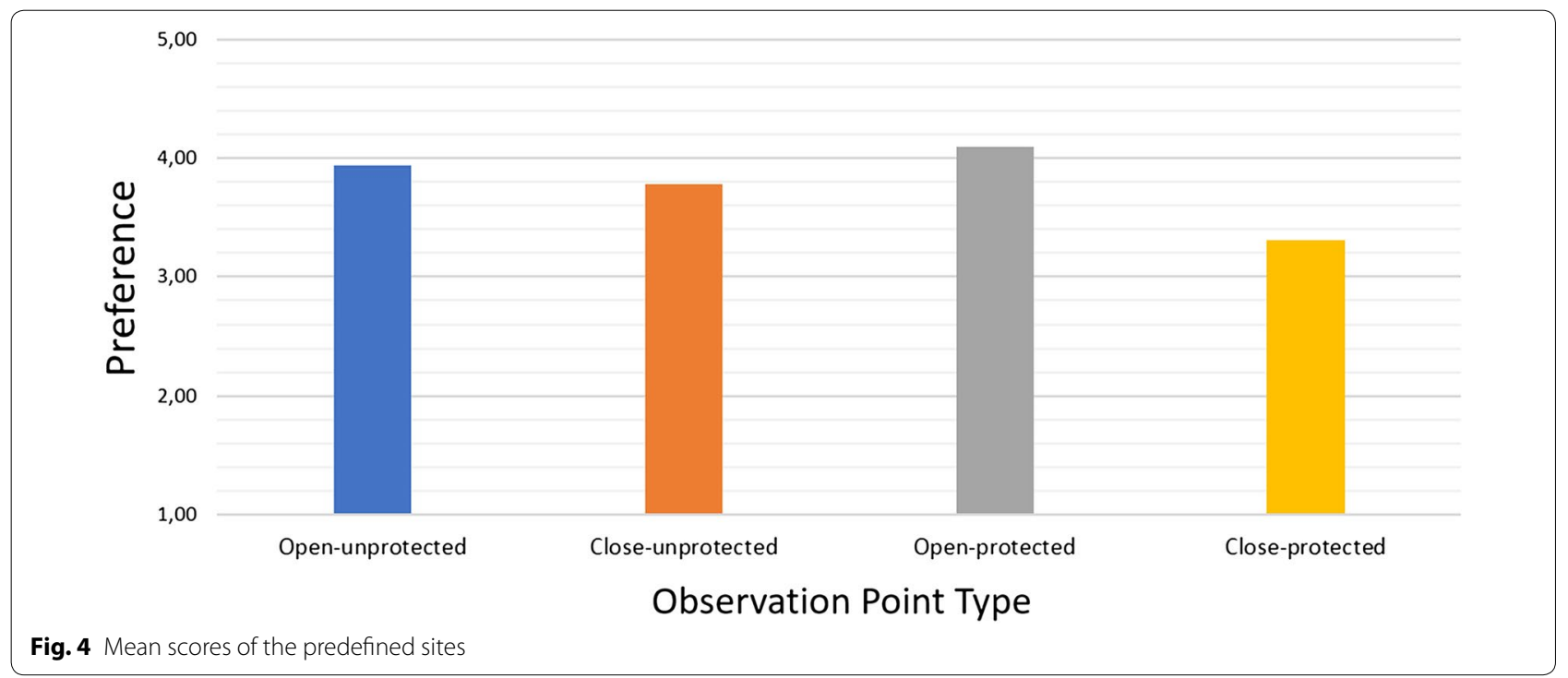



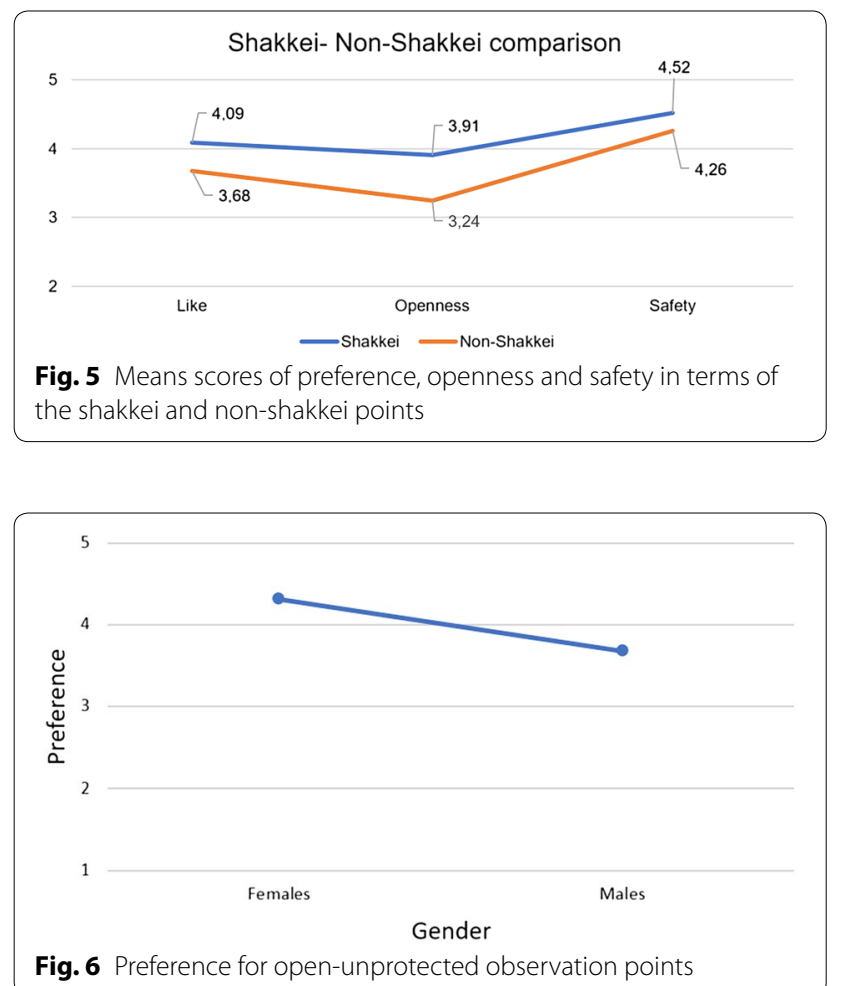

\section{Effective variables on general landscape preferences}

Multiple linear regression analysis was performed to identify the variables that significantly affect general landscape preferences (Table 5). In this analysis, in addition to variables such as openness, safety and perceived pleasantness of/disturbance from the background buildings, demographic variables such as gender, age, education level, nationality, the relation of the participant's occupation to design disciplines, and whether the participant had taken graduate level classes about natural environmental studies were examined. This analysis allowed us to observe the cumulative effect of all the variables on general landscape preferences instead of calculating correlations between the variables one by one.

According to the regression analysis (Table 5), three attributes significantly affect general landscape preferences: the perceived openness/closedness of a site, the perceived disturbance from/pleasantness of the buildings in the background, and the participant's nationality. Independent variables explained $34.7 \%$ of the variance in general landscape preferences $(\mathrm{F}=6.282, d f=10-118$, $\mathrm{p}<0.001)$. The perceived openness of a site and perceived pleasantness of/disturbance from the background buildings were found to be positive indicators of general landscape preferences, whereas nationality was a negative indicator.

\section{Effect of nationality}

When the results of the multiple regression analysis were investigated, it was observed that nationality had a negative coefficient in the regression equation. A variance test was performed for general landscape preferences by taking nationality as a dependent factor. The results showed that Japanese participants had significantly lower preference ratings (3.35) than foreign participants (4.22)

Table 5 Multiple linear regression analysis for the relationships between the variables and general landscape preferences

\begin{tabular}{|c|c|c|c|c|c|c|c|}
\hline \multirow[t]{2}{*}{ Model } & \multicolumn{2}{|c|}{$\begin{array}{l}\text { Unstandardized } \\
\text { coefficients }\end{array}$} & \multirow[t]{2}{*}{$\mathrm{t}$} & \multirow[t]{2}{*}{ Sig. } & \multicolumn{3}{|l|}{ Correlations } \\
\hline & B & Std. error & & & Zero-order & Partial & Part \\
\hline \multicolumn{8}{|l|}{ Regression model } \\
\hline (Constant) & 2.742 & 0.668 & 4.104 & 0.000 & & & \\
\hline The scene is (open/closed)** & 0.233 & 0.073 & 3.205 & $0.002^{* *}$ & 0.342 & 0.283 & 0.238 \\
\hline The place where I stand is (safe/unsafe) & 0.060 & 0.102 & 0.588 & 0.558 & 0.170 & 0.054 & 0.044 \\
\hline $\begin{array}{l}\text { The buildings in the background of the garden scene are } \\
\text { (pleasant/disturbing)** }\end{array}$ & 0.164 & 0.068 & 2.402 & $0.018^{* *}$ & 0.246 & 0.216 & 0.179 \\
\hline Building ratio in the scene & 0.009 & 0.007 & 1.273 & 0.205 & 0.128 & 0.116 & 0.095 \\
\hline Education on nature (nature class taken $=1$; not taken $=0$ ) & 0.346 & 0.272 & 1.271 & 0.206 & 0.178 & 0.116 & 0.095 \\
\hline Occupation (designer $=1$; non-designer $=0$ ) & -0.251 & 0.188 & -1.335 & 0.185 & -0.145 & -0.122 & -0.099 \\
\hline Nationality (Japanese $=1$; foreigner $=0$ ) $* *$ & -0.753 & 0.174 & -4.326 & $0.000^{* *}$ & -0.438 & -0.370 & -0.322 \\
\hline Gender (female $=1 ;$ male $=0$ ) & 0.080 & 0.154 & 0.515 & 0.608 & 0.060 & 0.047 & 0.038 \\
\hline Education level & -0.088 & 0.112 & -0.789 & 0.432 & 0.075 & -0.072 & -0.059 \\
\hline Age & 0.002 & 0.006 & 0.351 & 0.726 & -0.125 & 0.032 & 0.026 \\
\hline
\end{tabular}

$R=0.589 ; R^{2}=0.347 F_{(10-118)}=6.282, p<0.001$

** Significant at the $\mathrm{p}<0.05$ level 
$(\mathrm{F}=30.095, d f=1-127, \mathrm{p}<0.001)$. To examine the effect of nationality on general landscape preferences, the dataset was split into two distinct subsets in which one of them contained only Japanese subjects' preferences, while the other one contained only foreign subjects' preferences. Based on this division, the results of the analysis showed that foreign participants had significantly different mean preference scores for different observation points $(\mathrm{F}=3.297, d f=7-56, \mathrm{p} \leq 0.005)$, while this significance level was lower for Japanese participants $(\mathrm{F}=2.545$, $d f=7-57, \mathrm{p}<0.05)$. For Japanese respondents, Mt. Fujimi (4.00) and Nakanohashi-1 (4.00) were the most preferred sites, while foreign respondents liked Mt. Hakkei (4.86) the most. Additionally, the site called 'next to Tsubameno-ochaya' (2.88) was the least preferred by Japanese participants, whereas for foreign participants, 'the forest area surrounding Dai-sensui' (3.71) was the least preferred site. Moreover, Japanese visitors preferred 'shakkei points' (3.68) to the 'non-shakkei points' (3.22), but the difference was not significant $(\mathrm{F}=2.566, d f=1-63$, $\mathrm{p}>0.05$ ), whereas foreign visitors significantly preferred the 'shakkei points' (4.64) to the others (4.10) $(\mathrm{F}=8.427$, $d f=1-62, \mathrm{p} \leq 0.005)$. Furthermore, when the effect of the predefined categories of observation points on general landscape preferences was investigated separately for Japanese and foreign participants, a dramatic difference was observed between the two groups. According to the results of the analysis, foreign respondents significantly preferred the open-protected observation points (4.64) the most and closed-protected observation points (3.80) the least $(\mathrm{F}=6.859, d f=3-60, \mathrm{p}<0.001)$, and this result was consistent with the main dataset (see the section on the effect of prospect-refuge on general landscape preferences). However, this situation was different for Japanese respondents, as they significantly preferred the open-unprotected observation points (3.87) the most and closed-protected observation points $(2.88)$ the least $(\mathrm{F}=4.009, d f=3-61, \mathrm{p}<0.05)$. Another difference between Japanese and foreign participants was found for the correlation between the building ratio and general landscape preferences. In the foreign respondent data, no correlation was found between the building ratio and general landscape preferences $(r=-0.053, p>0.5)$, and the relationship between them was negative, as expected. On the other hand, Japanese respondent data showed a positive and significant correlation between building ratio and general landscape preferences $(r=0.257$, $\mathrm{p}<0.05)$.

\section{Effect of the high-rise buildings on general landscape preferences and prospect-refuge}

Bivariate correlation tests were performed to test the effect of high-rise buildings on general landscape preferences and prospect-refuge variables (Table 6). The results of the analysis showed that there were no significant correlations of the calculated building ratios with general landscape preferences $(r=0.128, p>0.05)$, perceived openness (prospect) $(\mathrm{r}=0.049, \mathrm{p}>0.5)$ and safety (refuge) $(r=0.018, p>0.5)$.

Furthermore, when the effect of the surrounding buildings on general landscape preferences was examined in the context of building ratio categorization (highlevel density/low-level density), no significant difference was found between them $(\mathrm{F}=0.055, d f=1-127$, $\mathrm{p}>0.05)$. In this case, it can be concluded that neither general landscape preferences nor the perceived attributes of prospect-refuge were affected by the building ratio. Moreover, the results showed no significant correlation between building ratios and the perceived disturbance from/pleasantness of the background buildings $(\mathrm{r}=0.010, \mathrm{p}>0.5)$.

On the other hand, there was a positive correlation between the perceived disturbance from/pleasantness of the background buildings and general landscape preferences $(r=0.246, p \leq 0.005)$. However, this correlation did not occur with the variables of prospect-refuge (perceived disturbance/pleasantness with openness $r=0.121$, $p>0.05$; perceived disturbance/pleasantness with safeness $r=0.110, p>0.05$ ). Though this finding suggests that perceived pleasantness of/disturbance from the background buildings might vary according to the physical characteristics of the sceneries, the variance test showed that there was no significant difference in the perceived pleasantness of/disturbance from the buildings across the sites $(\mathrm{F}=0.816, d f=7-121, \mathrm{p}>0.5)$.

Table 6 Correlation results of selected variables

\begin{tabular}{llll}
\hline \multicolumn{1}{c}{$\begin{array}{c}\text { Perceived } \\
\text { open- } \\
\text { closed }\end{array}$} & $\begin{array}{l}\text { Perceived } \\
\text { safe- } \\
\text { unsafe }\end{array}$ & $\begin{array}{l}\text { Building } \\
\text { ratio } \\
\text { in the scene }\end{array}$ & $\begin{array}{l}\text { Disturbing- } \\
\text { pleasant }\end{array}$ \\
\hline $\begin{array}{l}\text { I liked the scene from this point } \\
\text { Correlation } 0.342^{*}\end{array}$ & 0.170 & 0.128 & $0.246^{*}$ \\
Sig. $\quad 0.000$ & 0.054 & 0.149 & 0.005 \\
Perceived open-closed & & & \\
Correlation & 0.172 & 0.049 & 0.121 \\
Sig. & 0.051 & 0.584 & 0.174 \\
Perceived safe-unsafe & & 0.018 & 0.110 \\
Correlation & & 0.842 & 0.214 \\
Sig. & & & \\
Building ratio in the scene & & & 0.010 \\
Correlation & & & 0.914 \\
Sig.
\end{tabular}

*Significant at the $p \leq 0.05$ level 


\section{Discussion}

The results of this study emphasized the openness of a landscape setting as an essential indicator for an aesthetic assessment of a landscape. This result is consistent with previous research findings (Nasar et al. 1983; Ruddell and Hammitt 1987; Conrad 1993; Hagerhall 2000). In addition to the statement of Appleton (1975a), in which he indicated that Japanese gardens exhibit mainly refugerelated symbols, the results of this study demonstrated the additional importance of prospect-related symbols by indicating the degree of openness of a view as the most important determinant of general landscape preferences for all points. However, it is important to note that this does not necessarily prove the importance of openness in determining preferences. The fact that different participants assessed each observation point might affect the consistency of the results presented here. Therefore, the validity of this result should be tested with additional experiments questioning the same participants at each observation point.

The results showed that predefined protected sites and the perceived safety level of a site did not significantly influence general landscape preferences. This result partly confirmed the previous findings of Nasar et al. (1983), in which prospect was identified as the main indicator of preferences, whereas refuge exhibited a neutral effect. However, this result was also inconsistent with the findings of Ruddell and Hammitt (1987), Conrad (1993) and Hagerhall (2000), all of whom found that the refuge aspect of an environment is an important determinant of preferences. Furthermore, the fact that all the sites in the garden were perceived as safe by the participants in this study may be considered as a finding is indicative of the strong refuge-related character of the garden, which supports Appleton (1975a) statement regarding Japanese gardens. However, this perception might be the result of proper management in the garden, as connections of management and concern for the environment with the feeling of safety have been found in studies on urban parks, constructed environments and cultural landscapes (Taylor et al. 1985; Grahn 1991; Hagerhall 2000). This potential connection needs to be verified by further empirical studies with related variables.

When the predefined categories for the observation points were taken into account, the results showed evidence for the validity of prospect-refuge theory in Japanese gardens since the open-protected observation points were the most preferred. This result naturally lends support to the conclusion that the scenes with balanced prospect and refuge aspects are perceived as more aesthetic and are preferred. This finding is consistent with Conrad (1993), in which the author indicated that observation points with balanced prospect- and refugerelated features are preferable.

As Stamps (2014) noted with regard to the link between the Shakkei (borrowed scenery) technique of Japanese gardens and prospect-refuge theory, the Shakkei technique is an important factor affecting landscape preferences, and 'shakkei points' might have a proper setting for an observation point to exhibit balanced prospect- and refuge-related features. Moreover, the fact that Mt. Fujimi and Mt. Hakkei (Shakkei points) were found to be the most preferred and perceived as possessing the most open views in this study supports the statement of Appleton (1975a) in which he indicated that artificial hills (referred to as ornamental mounts) are elements of Japanese gardens that enhance their prospect quality. Labeled as 'shakkei points' in this study, Mt. Fujimi and Mt. Hakkei are two artificial hills where one can experience the aspects of prospect and refuge at the same time. The fact that they are also the most preferred sites suggests a connection between Shakkei settings and prospect-refuge theory. However, as mentioned previously, since the surrounding high-rise buildings obstruct the view of the garden, it is not possible to strongly emphasize the aesthetic experience of these sites (Mt. Fujimi and Mt. Hakkei) with regard to the Shakkei technique. Here, it should be noted that the appealing nature of these two sites could result from the experience of an overall view from a high position in the landscape, which is sometimes referred to as the aesthetic experience of 'overview' and which is related to the prospect aspect (Hagerhall 2000). Therefore, a precise link between the Shakkei technique and prospect-refuge theory in this garden can be explored by further empirical studies with the usage of simulated views.

When the demographic characteristics of the participants were examined, contrary to the findings of Nasar et al. (1983), no significant difference was found between female and male participants regarding perceived safety of the sites. This result is consistent with Lothian (2017), in which gender was not a significant determinant of preferences in 12 reviewed studies out of 16 . On the other hand, the results of this study showed that female participants preferred 'open-unprotected' observation points more than male participants did. This result contrasts with previous research findings (Nasar et al. 1983; Heerwagen and Orians 1993), which indicated that female visitors preferred enclosed and protected places, while for male visitors, the opposite was true. When these scenes (points 1 and 2 in Fig. 2) are examined to suggest a logical interpretation regardless of the background buildings, the scenes seem to offer a more natural feeling by being much closer to the water element in the garden. This finding may be explained by a higher prevalence of 
positive attitudes towards nature among women than men, which supports the findings of Strumse (1996). Furthermore, Woodcock (1982) found that women are more sensitive to a lack of coverage in clustered tree areas such as savannas. These points (open-unprotected) are similar to those Woodcock (1982) had described. Nevertheless, to explain why female participants in this survey preferred 'open-unprotected' scenes with more detailed evidence, further research with comprehensive variables should be conducted.

A number of studies examined the effect of familiarity on landscape preferences and had found that familiarity is influential in cross-cultural studies (Yang and Kaplan 1990; Kaplan and Herbert 1987; Hull and Reveli 1989; Nasar 1984). In this context, nationality, associated with being local, is considered an indicator of being familiar with the scene. Yang and Kaplan (1990) indicated that familiar environments were not necessarily favoured. Furthermore, Nasar (1984) stated that it is likely that locals would have lower preferences for the landscapes than foreigners. In this study, in light of the nationality factor, the main data was split into two groups as 'Japanese' and 'foreign' to examine whether there was a difference between the preferences of Japanese participants and foreign participants which may be caused by 'familiarity'. The results supported Nasar's (1984) observation since it was found that Japanese participants exhibited significantly lower general landscape preference ratings than the foreign participants. Additionally, the fact that foreign participants showed significantly different landscape preferences for the sites could be due to unfamiliarity. On the other hand, the results showed a strong and positive correlation between Japanese subjects' general landscape preferences and the building ratio in the scenes. This result implies that a high density of buildings in a scene is more preferable for Japanese visitors than a low-density of buildings. In this sense, although previous research on the effect of high-rise buildings on traditional Japanese gardens has revealed a negative effect of the buildings (Shinji et al. 1989; Arifin and Masuda 1997; Koizumi and Ishikawa 2007; Shinobe 2012; Lin et al. 2017), the results of this survey showed that Japanese visitors seem to prefer the views with highrise buildings from inside the garden. This finding is thought to be a contradiction in terms of familiarity since it is highly likely that Japanese visitors, especially if they live in Tokyo, are familiar with scenes filled with highrise buildings. This phenomenon could be interpreted as resulting from admiration for 'modernism', which, as part of urbanism, has stemmed from Western influence on Tokyo. Considering the history of vertical growth in Tokyo, this phenomenon is a relatively new one in Japan, as high-rise buildings were introduced in the city slowly, starting in the early 1970s. Due to an economic bubble, high-rise construction dramatically accelerated, and more than $89 \%$ of high-rise buildings in the city were built after 1991, despite minimal planning strategies. As a result, high-rise buildings were retrofitted into the existing urban fabric, which caused a 'chaotic morphology' (Perez 2014). In light of this, views with high-rise buildings may still be an unfamiliar phenomenon for many Japanese citizens, which may result in a feeling of admiration or excitement for the modernism and symbolic economic power of these buildings imposed by Western cultures. In this sense, as Dupré (1996) states, the daring heights of these buildings may excite the mind and heart. However, this result must be verified and discussed in further research, which should address the effect of highrise buildings in the context of visitors' aesthetic experiences with more comprehensive stimuli and additional respondents.

When the main dataset was analyzed with regard to the effect of the building ratio, neither general landscape preferences nor the perceived prospect-refuge attributes were found to be affected by the building ratio. On the other hand, a significant correlation was observed between perceived pleasantness of/disturbance from the buildings and general landscape preferences, which indicated that the general landscape preferences (like-dislike) of the participants who assessed the buildings as disturbing were lower compared to the general landscape preferences of the participants who found the buildings pleasant. This situation suggests that the subjective characteristics of observers may have a greater influence on their perception of the background building views. Moreover, it can be concluded that perceived pleasantness of/disturbance from the buildings is independent of the objective attributes of the scene and related to the personal characteristics and experiences of the observer. This hypothesis leads us to some new research questions, such as what are the subjective qualities of the observer; who finds the background buildings disturbing or pleasant; what are some alternative attitudes of the observer on background buildings; and what should be done to satisfy the observers who find the background buildings disturbing? These questions were tried to be investigated partially in another study which was the second phase of the survey (Senoglu et al. 2018). In their study, Senoglu et al. (2018) examined respondent features and their perceptions of the external high-rise building views from inside the garden. However, due to limited stimuli of the study, it was thought that a more detailed survey using simulations with controlled view change should be conducted to verify the results.

This study is limited because it only addressed one type of Japanese garden. Prospect-refuge theory may be 
examined again in other Japanese gardens to define the effect of prospect and refuge attributes on landscape preferences. Additionally, as mentioned before, the stimuli of the study are limited to eight sceneries. Further research may approach the issue with more comprehensive stimuli and a more detailed categorization of them that considers all the landscape elements in a scene. Furthermore, to observe the differences between observation points and to discuss each observation point's prospect and refuge attributes effectively, it is highly recommended that further research should question the same people at each observation point.

\section{Conclusion}

This study demonstrates that the Western concepts of landscape aesthetics can also explain the aesthetic experience in Japanese gardens. One of the evolutionary approaches in environmental aesthetics to explain landscape preferences by biological determinants, namely, prospect-refuge theory, was tested in a traditional Japanese garden, and supportive results were found; the in situ survey results showed that the locations that have open views and refuge-related features are the most preferred ones. Therefore, prospect-refuge theory can be considered a valid explanation for landscape preferences in Japanese gardens. Additionally, although many researchers have concentrated on the refuge-related aspects of Japanese gardens (Appleton 1975a; Kaplan et al. 1998; Inagami 2013, 2014), this research emphasized the importance of the prospect aspect in a traditional Japanese daimyo garden. Today, despite the fact that the prospect aspect of this garden has decreased due to the presence of surrounding high-rise buildings, this grand-scale garden is still perceived as open, especially from atop the artificial hills referred to as 'shakkei points.' Apparently, previous designers of Japanese gardens had a deep understanding of scenic characteristics and organized the sites around points from which distant scenery could be viewed. Consequently, these sites are still the most preferred ones in the garden. In accordance with the results, it is hypothesized that the logic behind the shakkei technique of Japanese gardens can be explained by prospect-refuge theory. However, to demonstrate the importance of this technique in the context of the aesthetic experience of Japanese gardens, further quantitative research with a broader approach should be conducted. Furthermore, the results of this study showed that visitors' perceptions of the prospect and refuge aspects of the garden are not affected by the surrounding high-rise buildings. However, it is highly recommended that such changes in the scenery of traditional gardens should be taken into consideration and their effect on the aesthetic experience of the gardens should be examined.
Traditional Japanese gardens are appreciated by people all around the world due to their sophisticated design principles, philosophical significance and visual richness that reflects the Japanese sense of beauty (Reid 2007; Lothian 2017; Bell 2007). Existing scientific literature that has focused on environmental aesthetics explicitly has underlined the uniqueness of the aesthetic experience of Japanese gardens (Carlson 2009; Saito 2007). Therefore, an understanding of the design principles of traditional Japanese gardens provided by an application of analytic methods given by landscape aesthetic theories that takes into account user experiences will guide and inspire contemporary designers to shape the conceptual foundations for creating successful designs.

\section{Abbreviations}

TMGBCPD: Tokyo Metropolitan Government Bureau of Construction Park Division; TMPA: Tokyo Metropolitan Park Association.

\section{Authors' contributions}

BS: found research question, designed the research, selected data collection methods, designed the experiment, took photos from the garden, calculated the average building densities, collected data from respondents, interpreted the results, wrote the final manuscript. HEO: data analysis, made the statistical investigations, reported the results. IK: managed the research procedure, gave advises to the respondent author, made corrections on drafted manuscript. All authors read and approved the final manuscript.

\section{Author details}

${ }^{1}$ Department of Landscape Architecture and Environmental Science, Chiba University Graduate School of Horticulture, 648 Matsudo, Matsudo City, Chiba 271-8510, Japan. ${ }^{2}$ Landscape Architecture, Architecture and Design Faculty, Van Yuzuncu Yil University, Van, Turkey.

\section{Acknowledgements}

The field survey was made possible by the allowance of Tokyo Metropolitan Government Park Association, Division of Cultural Property Gardens/Hamarikyu Gardens. Support from the manager of Hama-rikyu Gardens, Ms. Nakayama Natsuki and the staff in the garden office is gratefully acknowledged. We would also show our gratitude to Ms. Sofia Penabaz-Wiley and Ms. Libo He for assistance with in situ survey and Ms. Mayu Tatsuki and Mr. Mitsunari Terada for their help in preparing Japanese version of the questionnaire. We are also immensely grateful to Prof. Meryem Atik and Mr. Anthony Murithi for their comments that greatly improved the manuscript.

\section{Competing interests}

The authors declare that they have no competing interests.

\section{Availability of data and materials}

The dataset supporting the conclusions of this article is available in the "Figshare" repository, in this link: https://figshare.com/s/574bd94edb43450003d3.

\section{Ethics approval and consent to participate}

All procedures performed in the study involving human participants were in accordance with the ethical standards of the institutional and/or national research committee and with the 1964 Helsinki declaration and its later amendments or comparable ethical standards.

\section{Funding}

The corresponding author of this manuscript is a scholarship doctoral student at Chiba University, and her financial support has been given by MEXT (Monbukagakusho). 


\section{Publisher's Note}

Springer Nature remains neutral with regard to jurisdictional claims in published maps and institutional affiliations.

Received: 21 February 2018 Accepted: 5 July 2018

Published online: 17 July 2018

\section{References}

Akasaka M (2014) Whose view to Mount Fuji is in Tokyo? In: Dobričič S, Magnani C, Pedroli B, Strecker A (eds.). The issues on the vistas in townscapes. I Quaderni Di Careggi 6 (6):9-14. http://graspthefuture.eu/wp-content/ uploads/2017/03/6-2014-UNISCAP6-E-KR-Quaderni-di-Careggi-Sixth -issue-Common-Goods.pdf. Accessed 16 July 2017

Anonymous (2015) 高層ビルが借景に (High-rise buildings to borrow). https ://www.tripadvisor.jp/ShowUserReviews-g1066451-d2075268-r3222 42222-Former_Shiba_Rikyu_GardenMinato_Tokyo_Tokyo_Prefecture _Kanto.html. Accessed 24 Aug 2017

Anonymous (2016a) A modern concept of 'Shakkei' [Web log post]. https:// realjapanesegardens.wordpress.com/2016/01/20/a-modern-concept-ofshakkei/. Accessed 12 Aug 2017

Anonymous (2016b) Hamarikyu gardens - a secret Japanese Gardens in the heart of Tokyo. https://fastjapan.com/en/p1 10439. Accessed 24 June 2017

Appleton J (1975a) Landscape evaluation: the theoretical vacuum. Transactions of the Institute of British Geographers, London, pp 120-123

Appleton J (1975b) The experience of landscape. Wiley, London

Appleton J (1996) The experience of landscape. Wiley, London, p 282

Arifin NH, Masuda T (1997) The visual impact of building development on Ritsurin garden and its conservation. Landsc Res Jpn J JILA 60(4):315-323

Arifin NH, Masuda T (1998) Visitors'judgments on the scenery of Ritsurin garden. Landsc Res Jpn J JILA 61 (3):259-262

Bell S (2007) Landscape pattern, perception and process, 2nd edn. Routledge, London

Carlson A (2009) Nature and landscape: an introduction to environmental aesthetics. Columbia University Press, New York

Conrad J (1993) Prospect/refuge theory: an experimental approach. Unpublished Master's Thesis, Queensland University of Technology, Brisbane

Dosen AS, Ostwald MJ (2016) Evidence for prospect-refuge theory: a metaanalysis of the findings of environmental preference research. City Territory Archit 3(1):4. https://doi.org/10.1186/s40410-016-0033-1

Dupré J (1996) Skyscrapers. Black Dog \& Leventhal Pub, New York, p 119

European Landscape Convention. (2002). Council of Europe

Fairclough G, Lambrick G, McNab A (eds) (1999) Yesterday's world, tomorrow's landscape. The English Heritage Historic Landscape Project 1992-94. English Heritage, London

Grahn P (1991) Om parkers betydelse. Stad \& Land no 93. Swedish University of Agricultural Sciences, Alnarp

Hagerhall CM (2000) Clustering predictors of landscape preference in the traditional Swedish cultural landscape: prospect-refuge, mystery, age and management. J Environ Psychol 20(1):83-90

Heerwagen J, Orians G (1993) Humans, habitats and aesthetics. In: Kellert SR, Wilson EO (eds) The biophilia hypothesis. Island Press, Shearwater Books, Washington, pp 138-172

Hull RB IV, Reveli GR (1989) Cross-cultural comparison of landscape scenic beauty evaluations: a case study in Bali. J Environ Psychol 9(3):177-191

Inagami M (2013) Aesthetics and environmental enclosure in Japanese Zen gardens. In: Davis TJ, Passos P, Dicks M, Weast-Knapp JA (eds) Studies in perception and action XII. Psychology Press, Hove, pp 102-105

Inagami M (2014) Relationships between spatial and aesthetic feelings in Japanese Zen gardens. In Kozbelt A (Ed). Proceedings of the 23th Biennial Congress of the International Association of Empirical Aesthetics, pp 485-489

Ito T, Kawarada M (2000) Environmentalism in Japanese gardens. In: Environmentalism in landscape architecture. pp 245-268

Kaplan R, Herbert EJ (1987) Cultural and subcultural comparisons in preference for natural settings. Landsc Urban Plan 14:281-293

Kaplan R, Kaplan S (1989) The experience of nature: a psychological perspective. Cambridge University Press, Cambridge
Kaplan R, Kaplan S, Ryan RL (1998) With people in mind: design and management of everyday nature. Island Press, Washington

Kaymaz IC (2012) Landscape perception. In: Landscape planning. Dr. Murat Ozyavuz (Ed.), ISBN: 978-953-51-0654-8, InTech. http://www.intechopen .com/books/landscape-planning/landscapeperception. Accessed 18 May 2017

Kellert SR (2005) Building for life: designing and understanding the humannature connection. Island Press, Washington

Koizumi M, Ishikawa M (2007) A study of landscape structure in Dai-sensui and Yokobori area of Hamarikyu Garden [Tokyo, Japan]. J Jpn Instit Landsc Archit 70(5):497-500

Lin L, Homma R, Iki K (2017) Visual impact analysis and control method of building height for landscape preservation of the traditional gardens: a case study on the Suizenji Jojjuen in Kumamoto City. In: Pan Q, Li W (eds) Smart growth and sustainable development. GeoJournal Library, vol 122. Springer, Cha, pp 115-125

Lippmann PC (2010) Evidence-based design of elementary and secondary schools: a responsive approach to creating learning environments. Wiley, New York

Lothian A (2017) The science of scenery: how we see scenic beauty, what it is, why we love it, and how to measure and map it. Create Space, Sydney

Mumcu S, Düzenli T, Özbilen A (2010) Prospect and refuge as the predictors of preferences for seating areas. Sci Res Essays 5(11):1223-1233

Nasar JL (1984) Visual preferences in urban street scenes: a cross-cultural comparison between Japan and the United States. J Cross Cult Psychol 15(1):79-93

Nasar JL, Julian D, Buchman S, Humphreys D, Mrohaly M (1983) The emotional quality of scenes and observation points: a look at prospect and refuge. Landsc Plan 10(4):355-361

Nassauer II (1992) The appearance of ecological systems as a matter of policy. Landsc Ecol 6(4):239-250

Nassauer JI (1995) Messy ecosystems, orderly frames. Landsc J 14:161-170

Nassauer JI (1997) Cultural sustainability: Aligning aesthetics and ecology. In: Nassauer JI (ed) Placing nature: culture and landscape ecology. Island Press, Washington DC, pp 67-83

Nitschke G (1993) Japanese gardens: right angle and natural form, 1st edn. Köln, Taschen, p 181

Norberg-Schulz C (1980) Genius loci: toward a phenomenology of architecture. Rizzoli, New York

Orians GH (1980) Habitat selection: general theory and applications to human behaviour. In: Lockard JS (ed) The evolution of human social behaviour. Elsevier, New York, pp 49-66

Perez RIP (2014) The historical development of the Tokyo skyline: timeline and morphology. J Asian Archit Build Eng 13(3):609-615

Reid GW (2007) From concept to form: in landscape design, 2nd edn. Wiley Publishing, New York

Ruddell EJ, Hammitt WE (1987) Prospect refuge theory: a psychological orientation for edge effect in recreation environments. J Leisur Res 19(4):249-260

Saito Y (2007) The moral dimension of Japanese aesthetics. J Aesth Art Critic 65(1):85-97

Scoble E (2015) The making of a mountain: Mount Fuji, miniature Fujis and the cultural narrative of Edo. Honors Thesis Collection. 275. http://repository .wellesley.edu/thesiscollection/275. Accessed 21 July 2017

Senoglu B, Oktay HE, Kinoshita I (2018) Visitors' perception of high-rise building effect on the scenery of traditional gardens: a case study in Hama-rikyu Gardens, Tokyo. Civil Eng Archit 6(3):136-148

Shinji I (2015) What is a daimyo teien? - The ideal Edo period garden, combining form and function. http://jgrmag.com/en/feature/what-is-a-daimy o-teien-the-ideal-edo-period-garden-combining-form-and-function. Accessed 14 Aug 2017

Shinji I, Shimizu T, Takemata T (1989) The present situation of landscape destructions on the cultural property gardens in Tokyo. J Jpn Instit Landsc Archit 52(5):43-48

Shinobe $H$ (2012) A study on the scenery protection around the garden in the city — case study of five traditional Japanese landscape gardens. J City Plan Instit Jpn 47(3):625-630

Shirahata Y (2016) Daimyo Garden. Translated by Imoto Chikako and Kynne E. Riggs. International Research Center for Japanese Studies, Koyto, pp 85-135 
Stamps AE (2014) Literature review of prospect and refuge theory: the first 214 references. Institute of Environmental Quality, San Francisco, CA. https:// www.Researchgate.net. Accessed 16 Aug 2017

Strumse E (1996) Demographic differences in the visual preferences for agrarian landscapes in western Norway. J Environ Psychol 16(1):17-31

Sullivan C, Boults E (2010) Illustrated history of landscape design. Wiley, New York, p 112

Tamurai T (1935) Art of the landscape garden in Japan. Kokusai Bunka Shinkokaki (The Society for International Cultural Relations), Tokyo

Taylor RB, Shumaker SA, Gottfredson SD (1985) Neighborhood-level links between physical features and local sentiments. Deterioration, fear of crime and confidence. J Archit Plan Res 17:261-275

Timmons MB (2012) An analysis of the participatory model of aesthetics and Japanese gardens. http://wesscholar.wesleyan.edu/cgi/viewconten t.cgi?article $=1804 \&$ context=etd_hon_theses. Accessed 24 July 2017

TMGBCPD (2017) Tokyo metropolitan government bureau of construction park division. The cultural asset garden in Tokyo. Preservation Utilization Plan (Hama-rikyu Garden), Tokyo (in Japanese)

TMPA (2006) Tokyo Metropolitan Park Association. Tidal pond carrying water from the Tokyo Bay Hama-rikyu Gardens. 2017. https://www.tokyo-park. or.jp/english/park/detail_04.html. Accessed 24 Aug 2017
TMPA (2008) Tokyo Metropolitan Park Association Hama-rikyu Gardens. 2017 http://teien.tokyo-park.or.jp/en/hama-rikyu/outline.html. Accessed 24 Aug 2017

Tuan Y (1974) Topophilia. Prentice-Hall, Englewood Cliffs

Ulrich RS (1983) Aesthetic and affective response to natural environment. In: Altman I, Wohlwill JF (eds) Behavior and the natural environment. Plenum Press, ABD New York

Ulrich RS (1993) Biophilia, Biophobia and natural landscapes. In: Kellert SR, Wilson EO (eds) The biophilia hypothesis. Island Press, Washington, D.C. pp 73-137

Wilson EO (1984) Biophilia. Harvard University Press, Cambridge, p 157

Woodcock D (1982) A functionalist approach to environmental preference. University of Michigan, Ann Arbor

Yang BE, Brown TJ (1992) A cross-cultural comparison of preferences for landscape styles and landscape elements. Environ Behav 24(4):471-507

Yang BE, Kaplan R (1990) The perception of landscape style: a cross-cultural comparison. Landsc Urban Plan 19:251-262

Zube EH, Sell JL, Taylor JG (1982) Landscape perception: research, application and theory. Landsc Plan 9(1):1-33

Zube EH, Simcox DE, Law CS (1987) Perceptual landscape simulations: history and prospect. Landsc J 6:62-80

\section{Submit your manuscript to a SpringerOpen ${ }^{\circ}$ journal and benefit from:}

- Convenient online submission

- Rigorous peer review

- Open access: articles freely available online

- High visibility within the field

- Retaining the copyright to your article

Submit your next manuscript at $\boldsymbol{\nabla}$ springeropen.com 